Canon Kirkland, The King's School, Ely. The pamphlet contains a number of very useful hints for first aid in the laboratory, which have been compiled by the Science Masters' Association and the Association of Women Science Teachers, and it should be very useful in the school laboratory. It should be noted, however, that the administration of an emetic, particularly salt solution, as stated, is not advisable in the case of mercuric chloride without first giving immediately white of egg: the section on poisons is not sufficiently detailed to be of much real value. The staternent that "the naphtha used for storing sodium should be of the native rock-oil variety" is rather obscure.

\section{Ross Institute and Hospital for Tropical Diseases}

Reports of the annual general and extraordinary general meetings of the Ross Institute and Hosnital for Tropical Diseases, held on November 27, have now been released for circulation. At the eighth ordinary general moeting, the chairman, Sir Charles McLeod, surveyed the work of the Institute during the year, and the Council and Executive Committee were re-elected. At the extraordinary meeting, it was resolved to approve and confirm two agreements made between the Ross Institute, of the one part, and the London School of Hygiene and Tropical Medicine, and the Seamens' Hospital Society, respectively, of the other part, whereby the Ross Institute is amalgamated with the London School of Hygiene and Tropical Medicine, and the Ross Hospital is incorporated in the Seamens' Hospital Society by the establishment of a "Ross Ward" in their Hospital for Tropical Diseases. The Court and Senate of the University of London have expressed their satisfaction respecting the arrangement with the Sehool of Hygiene. The Ross Institute thus comes to an end, but the name of Ross will still be perpetuated in the new amalgamations.

\section{Gift to British Association}

THE Committee formed in Leicester in connexion with the meeting of the British Association there in $1933 \mathrm{had}$ a surplus of $£ 1,000$ in hand after meeting all the local expenses of the meeting. This sum has been handed over to the Association, to form the "Leicester and Leicestershire Fund, 1933" for the assistance of a student or students working for the advancement of science. The fund will be administered by the Council of the Association, and, when possible, assistance will be given preferably to a Leicester or Leicestershire student or worker. The Council, in accepting the gift, has expressed its appreciation of the action of the Committee "in thus confirming, in a manner without precedent in the history of the Association, their interest in the advancement of science".

\section{Continuation of Empire Marketing Board Research Work}

Mr. G. GLedhILL, in the House of Commons on February 6, asked Mr. J. H. Thomas, Secretary of State for Dominion Affairs, if any arrangements have been made for carrying on the racearch work previously undertaken by the Empire Marketing Board. In a written answer, Mr. Thomas stated that such arrangements are being made. It is estimated that the cost of such research work in the financial yoar 1934-35 will reach $£ 200,000$, of which some $£ 85,000$ will be borne by other Governments of the Empire or by the institutions or industries concerned.

\section{Announcements}

Prof. P. M. S. BLackett will give a course of three lectures on "Cosmic Radiation" at Birkbeck College, Bream's Buildings, E.C.4, on Tuesdays at 6 p.m. commencing on February 20. Admission to the lectures will be free without ticket.

THE following appointments in the Colonial Agricultural Service have recently been made : C. A. North-Coombes, to be agronomist, Department of Agriculture, Mauritius ; C. J. Lewin, chief agriculturist, to be director of agriculture, Northern Rhodesia; Capt. J. P. A. Morris, deputy director of animal health, to be director of animal health, Northern Rhodesia.

Ar the annual general meeting of the Royal Astronomical Society, held on February 9, the following officers were elected: President, Prof. F. J. M. Stratton; Vice-Presidents, Sir Arthur S. Eddington, Mr. John Evershed, Dr. H. Spencer Jones and Dr. W. J. S. Lockyer ; Treasurer, Mr. J. H. Reynolds; Secretaries, Mr. W. M. H. Greaves and Dr. W. M. Smart ; Foreign Secretary, Prof. Alfred Fowler; New Members of Council, Prof. H. Dingle, Sir Frank W. Dyson, Prof. H. F. Newall, Mr. W. H. Steavenson.

In Nature of December 23, 1933, p. 963, under the title "Study of Canadian Coals", a note appeared referring to a report by R. E. Gilmore and R. A. Strong in the Canadian Mining and Metallurgical Bulletin (p. 317, 1933), published by the Canadian Institute of Mining and Metallurgy. The journal was incorrectly quoted as the Journal of Canadian Mining and Metallurgy.

Applicatrons are invited for the following appointments, on or before the dates mentioned :-A lecturer in mathematics at Darlington Training College-The Principal (Feb. 21). A museum assistant (male) at the Leicester Museum and Art Gallery -The Director (Feb. 28). Staff tutors in psychology, political soience, etc., at the University of London-The Joint Hon. Secretaries (Tutorial Classes), University of London, South Kensington, S.W.7 (March 1). A Wakefield lecturer in aeronautics at University College, Hull-The Registrar (March 7). A probationary assistant engineer in the Post Office Engineering Department-The Secretary, Civil Service Commission, Burlington Gardens, London, W.1 (March 8). A Kennedy professor of engineering at University College, London-The Academic Registrar, University of London, S.W.7 (April 11). 